\title{
A quantitative assessment of the ecological value of sycamore maple habitats in the French Alps
}

\author{
Yoan PAILleT ${ }^{*}$, Frédéric ARCHAUX ${ }^{2}$, Vincent $_{\text {BRETON }}{ }^{1}$, Jean-Jacques BruN $^{1}$ \\ ${ }^{1}$ Cemagref, UR EMGR, Grenoble, 2, rue de la Papeterie BP 76, 38402 Saint-Martin-d'Hères, France \\ ${ }^{2}$ Cemagref, UR EFNO, Nogent-sur-Vernisson, Domaine des Barres, 45290 Nogent-sur-Vernisson, France
}

(Received 11 March 2008; accepted 1 July 2008)

Keywords:

Acer pseudoplatanus /

Chartreuse /

indicators /

naturalness /

ecological value

\author{
Mots-clés : \\ Acer pseudoplatanus / \\ Chartreuse / \\ indicateurs / \\ naturalité / \\ valeur écologique
}

\begin{abstract}
- Naturalness is an important criterion in nature conservation assessment. At the stand-level, such assessment must be based on objective and quantifiable indicators measurable in the field.

- In this study, we used a multi-criterion method based on the difference between a Natural Value $(\mathrm{NV})$ and a Conservation Value (CV) to quantify the ecological value of sycamore maple patches compared to the surrounding mixed forests. Indeed, sycamore habitats are considered of high natural and conservation value both by naturalists and by European institutions.

- Our results showed that the natural and conservation values were significantly higher for the sycamore forests than for the surrounding mixed forests and that this assessment did not depend on abiotic factors such as elevation or aspect. Actually, naturalness of structure and composition in the sycamore habitats was higher than for mixed forests and allowed us to differentiate between the two habitats.

- Managers could easily use this method in order to assess the ecological value of small habitats in mountainous regions and to provide guidelines for close-to-nature and conservation-related silviculture.
\end{abstract}

Résumé - Une évaluation quantitative de la valeur écologique des érablaies de versant dans les Alpes françaises.

- La naturalité est un critère important pour l'évaluation de mesures conservatoires des écosystèmes. Au niveau local, une telle évaluation doit être basée sur des indicateurs objectifs et quantifiables sur le terrain.

- Dans cette étude, nous avons utilisé une méthode multicritères basée sur la différence entre Valeur Naturelle (NV) et Valeur Conservatoire (CV) pour quantifier la valeur écologique des érablaies de versant à érable sycomore (Acer pseudoplatanus L.) par comparaison avec les peuplements mixtes de hêtraie-sapinière-pessière avoisinants. En effet, les naturalistes ainsi que l'Union Européenne considèrent que les érablaies de versant ont une valeur de conservation et de naturalité élevée.

- Nos résultats montrent que les valeurs naturelle et de conservation sont significativement plus élevées pour l'érablaie que pour la forêt mixte avoisinante et que cette évaluation ne dépend pas de facteurs abiotiques tels que l'altitude ou l'exposition. En fait, la naturalité de structure et de composition des érablaies de versant sont plus fortes que celles des forêts mixtes et permettent de différencier les deux habitats en termes de valeur écologique.

- Les gestionnaires peuvent facilement utiliser cette méthode pour évaluer la valeur écologique de petits habitats en zone de montagne, ce qui permet d'établir des orientations sylvicoles pour une gestion conservatoire et proche de la nature.

\footnotetext{
* Corresponding author: Yoan.Paillet@ cemagref.fr
} 


\section{INTRODUCTION}

In an attempt to halt the current erosion of biodiversity, international authorities are making important decisions affecting mid- and long-term planning - e.g. the 2010 European biodiversity target. The resulting nature conservation imperatives require clearly defined methods to assess the ecological value of the ecosystems involved, in terms of conservation and management (Ehrlich, 1996).

As the debate on nature conservation reaches ethical, philosophical and technical spheres (Siipi, 2004), naturalness emerges as a holistic approach, more related to habitats than individual species (Angermeier, 2000). Naturalness may be used as a measure of conservation value but also as a state descriptor (Machado, 2004). Although some authors consider that this distinction remains difficult to assess in a quantitative way (Anderson, 1991; Gotmark, 1992), several studies in the last decade have proposed methods to assess and quantify naturalness and conservation significance of a variety of ecosystems from the global (e.g. Beazley et al., 2005) to the local scale (Bartha, 2004; Uotila et al., 2002). In forest ecology, studies have mostly focused on natural forest dynamics (Korpel, 1995; Oldeman, 1990) and forest conservation and management (Colak et al., 2003; Neumann and Starlinger, 2001).

Criteria and indicators are widely used in forest management evaluation, particularly when sustainable management is targeted (e.g. Bridge et al., 2005). "Indicators" quantify measurable features of ecosystems whereas "criteria" are global indices more related to ecological processes (Frego, 2007). Criteria encompass the values of several different indicators and allow users to have a more comprehensive view of the assessment. This double approach is useful for managers since indicators could provide guidelines for concrete conservationoriented measures (e.g. favouring deadwood). But where the use of indicators is limited in application (Lindenmayer et al., 2000), criteria could provide integrated descriptors useful for policy makers because of their more holistic and pedagogical values (see e.g. Bartha et al., 2006 for a study at the national scale). As a consequence, criteria and indicators could be used complementarily to describe the ecological value of forest ecosystems.

In this context, the ecological assessment of forest stands is potentially useful because the assessed units (i.e. stands) are often the same as the management units. In French and Belgian forests, Du Bus de Warnaffe and Devillez (2002) have proposed a multi-criterion method to evaluate the ecological value of a forest ecosystem at the local level. This quantitative method is based on a classical criterion-indicator hierarchic system. The authors define two groups: criteria/indicators of natural value (NV) - which quantify the ecosystem deviation from the supposed primeval state in terms of composition, structure and function - and criteria/indicators of conservation value $(\mathrm{CV})$ - which quantify the ecosystem's potential to host rare or declining species, plant communities or ecotypes.

In our study, we focused on small habitat fragments because they can be seen as basic descriptive units in forest conservation (Peterken, 1996). Fragmented patches of sycamore maple
(Acer pseudoplatanus L.) habitat have traditionally been given a high ecological value by naturalists, but this view is essentially empirical and had never been quantified by using field measurements.

In this paper, we have adapted the method proposed by $\mathrm{Du}$ Bus de Warnaffe and Devillez to quantify the ecological value of sycamore maple habitats and the surrounding mixed forests. Our aim was to check whether the proposed multi-criterion method confirms the empirical naturalists' statement. On this basis, we hypothesized that sycamore maple habitats would have a higher ecological value than the surrounding mixed forest, in terms of conservation value and, very probably, also in terms of natural value. We then analysed the effects of biotic and abiotic factors on the global assessment. In this paper, we also discuss the limits and possible improvements of the method.

\section{MATERIALS AND METHODS}

\subsection{The study site}

The Massif de la Chartreuse is a pre-alpine mountain range located in eastern France (Fig. 1). The climate is under strong oceanic influence, with an average precipitation of $2046 \mathrm{~mm}$ per year at $1000 \mathrm{~m}$ a.s.l. A large part of this precipitation falls as snow (on average $4.4 \mathrm{~m}$ per year). Monthly mean temperatures vary from $0.1{ }^{\circ} \mathrm{C}$ in January to $16.2{ }^{\circ} \mathrm{C}$ in July. The annual mean temperature is $10.4{ }^{\circ} \mathrm{C}$. The mountain range is calcareous, mainly characterized by high Urgonian cliffs and large scree deposits down the slopes. Despite the settlement by Chartreux monks during the 11th century (Chevallier and Couailhac, 1983; Lavauden, 1905), the vegetation has never been strongly influenced by human activity due to difficulty of access. While considerable deforestation has occurred elsewhere in the Alps, the Chartreuse has been quite well-preserved (Brossier, 1954).

The current landscape is mainly composed of woodlands, which cover $65 \%$ of the area (compared with the national average of $27 \%-$ IFN, 2005). The rest of the area is pastureland, which often tends to naturally reforest, due to land abandonment. The main forest type is typically mixed beech-fir-spruce (Fagus sylvatica L., Abies alba Mill. and Picea abies (L.) Karst.), with variations in the proportions of the dominant species roughly depending on elevation: beech is dominant at lower elevations (below $600 \mathrm{~m}$ ), fir, beech and spruce are mixed in the montane range (600-1200 m), while spruce becomes dominant in the subalpine range (above $1200 \mathrm{~m}$ ) (Bartoli, 1962; Pache, 1998).

We compared sycamore maple habitat (hereafter "sycamore habitat") with surrounding mixed beech-fir-spruce stands (hereafter "mixed forest") in a study area located between $450 \mathrm{~m}$ and $1650 \mathrm{~m}$ a.s.l. The sycamore habitats belong to the Tilio-Acerion alliance and occur on slopes, screes and in ravines (European classification EUR27: 9180). They are registered in Natura 2000 Appendix V for their "remarkable biological value, scarcity and high level of naturalness" (see European Commission, 2003). However, the natural dynamics of these habitats remain poorly known (Paillet and Brun, 2004). The Tilio-Acerion alliance contains five sycamore habitat associations: Arunco-Aceretum, Phyllitido-Aceretum, CorydalidoAceretum, Sorbo-Aceretum, Ulmo-Aceretum (Rameau et al., 2000; Rameau et al., 1993). The first three associations are found mostly in the montane range, whereas the last two belong to the subalpine range (Clot, 1990). Probably due to the combined factors of their 


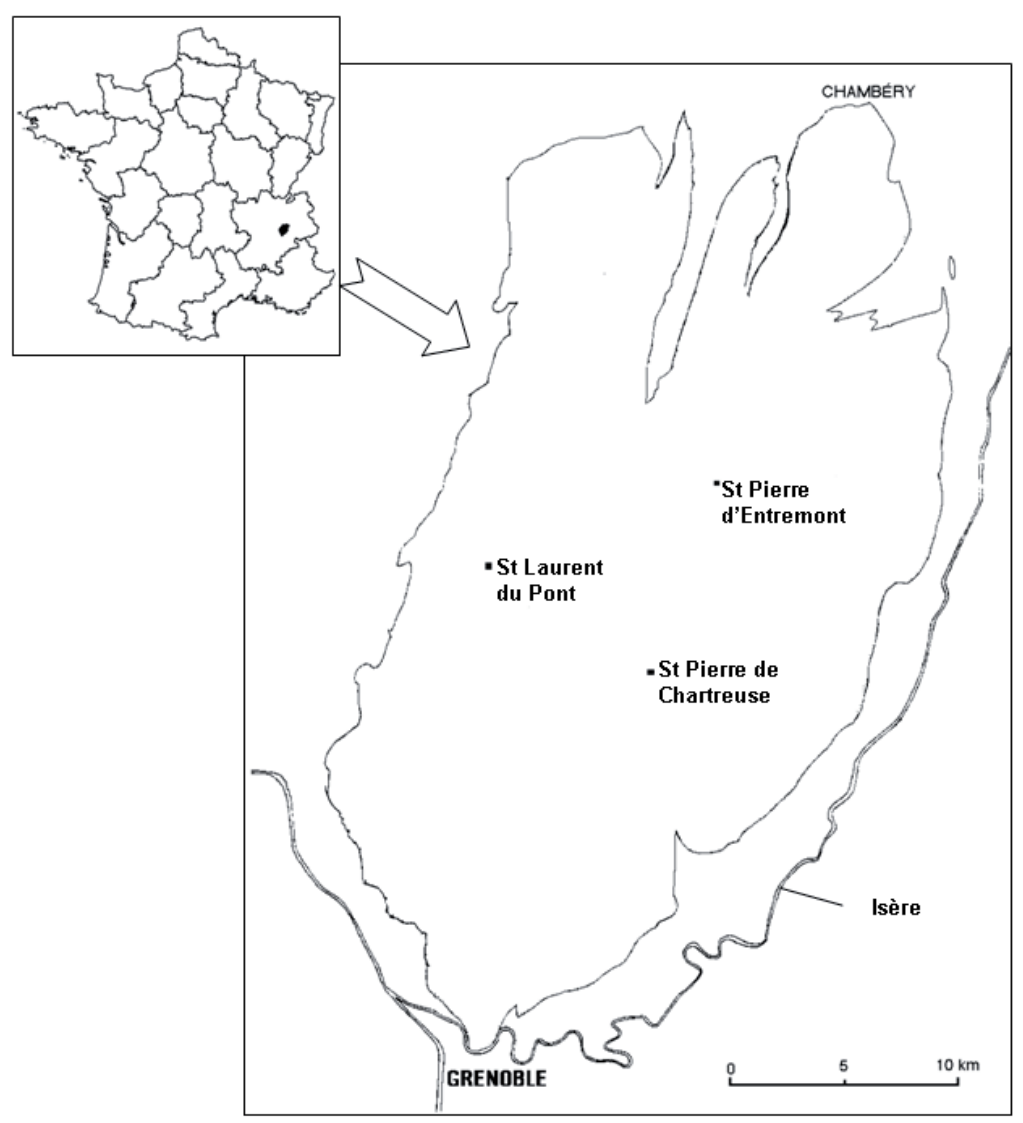

Figure 1. Location of the study area: le massif de la Chartreuse (France).

limited economic interest, their role in preventing soil erosion and their protected status in Europe, these habitats have remained basically unmanaged and are likely to be close to their natural state. This is particularly true in the Chartreuse, where history and topographic conditions favoured their conservation. However, sycamore habitats sometimes are damaged during harvesting of other more commercial species due to their position in ravines.

\subsection{The sampling design and measured indicators}

We used the National Alpine Botanical Conservatory of GapCharance database and floristic inventories from F. Clot in TilioAcerion habitats in the Alps (Clot, 1990) to reveal the main natural drivers of plant communities in these habitats. A correspondence analysis of the inventories from the Conservatory database (results not shown) confirmed the dominant influence of elevation and aspect on variations in the species composition of sycamore habitats in the Chartreuse, as Clot had highlighted for all of the Alps.

For our sampling design, we imperfectly crossed two factors, elevation and aspect, each including three classes (Tab. I). Actually, a third factor, association, was determined a posteriori so the sample was not balanced for this factor: Phyllitido-Aceretum represented half of the sample and Arunco-Aceretum a third, whereas the other associations were present at only one site. Undetermined associations occurred at two sites. Twenty-four study sites comprised our sample set (Tab. I).

In order to compare the two different habitats (sycamore habitats and mixed forest) in similar ecological conditions, on each site we set up paired circular $400 \mathrm{~m}^{2}$ plots - one in a sycamore stand and one in the mixed forest at a distance of $100 \mathrm{~m}$ downslope. On each plot, we described the ecological conditions (aspect, elevation, slope, soil types... ) and inventoried the vascular plants using the AbundanceDominance method (Braun-Blanquet, 1932). The censuses were carried out by one observer, which avoided possible bias as suggested by Archaux et al., (2006).

To assess the ecological value, we followed the same hierarchic approach as Du Bus de Warnaffe and Devillez (Tab. II). In the original article, the authors distinguished between two methods of assessment which differ depending on the scale of the study: the large scale method (so-called "massif method") which can be used for areas ranging from 50 ha to 1000 ha and the stand level method, which is adapted to areas ranging from 0.2 ha to 50 ha. We integrated indicators from the stand level method in our field sampling protocol. As the authors specified, the method can be adapted to a particular context by selecting or modifying more relevant indicators for the studied case (Tab. II). Here, we distinguished:

(i) Unmodified indicators

The cover of native tree species, the silvicultural treatment, the intensity of tourist activity, the sensitivity/vulnerability of the site, the 
Table I. The sampling design compares sycamore habitats and surrounding mixed forests, depending on elevation and aspect. On each of the 24 sites, paired $400 \mathrm{~m}^{2}$ circular plots in the sycamore habitat and the mixed forest were set up at a distance of $100 \mathrm{~m}$. Sycamore habitat associations are: $\mathrm{AA}=$ Arunco-Aceretum $; \mathrm{PA}=$ Phyllitido-Aceretum $; \mathrm{CA}=$ Corydalido-Aceretum $; \mathrm{SA}=$ Sorbo-Aceretum $; \mathrm{UA}=$ Ulmo-Aceretum; $\mathrm{ND}=$ Undetermined type.

\begin{tabular}{|c|c|c|c|c|c|}
\hline & & \multicolumn{4}{|c|}{ Elevation $(\mathrm{m})$} \\
\hline & & $450-850$ & $850-1250$ & $1250-1650$ & Total \\
\hline \multirow[t]{4}{*}{ Aspect } & North & 3 & 4 & 3 & 10 \\
\hline & East or West & 3 & 3 & 3 & 9 \\
\hline & & $(1 \mathrm{PA}, 1 \mathrm{CA}, 1 \mathrm{ND})$ & (2AA, 1PA) & (1AA, 1PA, 1UA) & \\
\hline & Total & 6 & 10 & 8 & 24 \\
\hline
\end{tabular}

number of vascular plant species, and other types of human intervention were directly recorded in classes in the field (see Tab. II for the definition of each class). The vertical heterogeneity was calculated after a visual assessment of the percentage of cover of $N$ vegetation strata. The index is comprised between 0 and 1 and calculated as follows:

$H V=($ Number of strata with a cover $>10 \%) \times($ Sum of cover $) /$ $\left(100 \times N^{2}\right)$ where $N$ is the number of strata. The value attributed to this index depends on the forest's developmental phase (Tab. II).

The total amount of deadwood and the eco-unit size were recorded directly in the classes provided by Du Bus de Warnaffe and Devillez (2002, Tab. II). The authors consider the eco-unit size as an indicator of forest naturalness because natural forest dynamics favours patchy forest stands with small eco-units; hence, the smallest the eco-unit, the more natural is the forest (see e.g. Standovar et al., 2006).

The phytocœnosis integrity is the ratio of the number of species of a given normative group within each plot to the total number of species in the normative group. We defined the normative floristic composition for the alliance and the Tilio-Acerion associations using the work of F. Clot (1990) and the National Alpine Botanical Conservatory of Gap-Charance floristic database for the Chartreuse. For the mixed forest, we used J.-C. Rameau et al. (2000; 1993). To assess the scarcity of the plant group (e.g. alliance), we used European, national and local inventories and red lists .(European Commission, 2003) (see Tab. II for the definition of each class). The scarcity of vascular plant species was calculated for each inventory as the sum of the individual scarcity of each plant with the following possible values: 1 for ordinary species, 3 for widespread species, 4 for rare or declining species and 5 for very rare or endangered species (the value 2 is omitted by authors, see Appendix 1 for details). This value was weighted by the Braun-Blanquet abundance $(a b)$ index. As this sum is comprised between 0 and 5 but rarely exceeds 3 , the correction factor $5 / 3$ was integrated into the formula:

$$
\begin{aligned}
R e & =(5 / 3) \times\left[\left(\sum \text { ab ordinary } \mathrm{sp} .\right)+3 \times\left(\sum \text { ab widespread } \mathrm{sp} .\right)\right. \\
& +4 \times\left(\sum \text { ab rare or declining } \mathrm{sp} .\right) \\
& \left.+5 \times\left(\sum \text { ab very rare or endangered } \mathrm{sp} .\right)\right] /\left(\sum \text { ab all } \mathrm{sp} .\right) .
\end{aligned}
$$

(ii) Adapted indicators

The total export of ligneous biomass was estimated from management plans and then adjusted in the field by observing the number of stumps resulting from harvesting on each stand (Tab. II). Remarkable structural stand features were: trees with potential nesting holes, a multi-stratified canopy and an exceptional amount of natural deadwood.

(iii) Added indicators

We considered the presence of remarkable trees (broadleaved trees with $\mathrm{DBH}>75 \mathrm{~cm}$ and/or partially or totally hollow living trees) as remarkable structural stand feature. These were not included in the original method.

These three categories of indicators are summarized in the Table II.

(iv) Excluded indicators

The number of cavity-nesting bird species, and the number of species from taxonomical groups other than plants were excluded because we could not precisely evaluate whether the species were strictly dependent on sycamore habitats or not. Neither the number of saproxylic species nor the number of epiphytic species were included since they cannot be precisely assessed without the intervention of a specialist. We excluded the indicator horizontal heterogeneity of the tree layer, which corresponds to the variation coefficient of the distance between trunks larger than DBH $10 \mathrm{~cm}$ (20 trees randomly selected per $0.5 \mathrm{ha}$ ), because it was too much time-consuming to take into account in the case of sycamore habitats. The vascular plant specificity for the habitat concerns the rare or declining vascular plants more or less restricted to a given habitat. It is calculated as the ratio between rare (or declining) individual specificity of plant species and the total number of rare (or declining) plant species on the plot. As no reference indicating strict specificity of plant species to sycamore habitats was available, we excluded this indicator (but see discussion). The integration of sycamore habitat in an ecological network was excluded despite the importance of such an indicator in ecological assessment (see discussion). Indeed, it was extremely difficult to delineate sycamore habitat patches both in the field and using aerial photographs. Moreover, no habitat map was available at the time of the study.

\subsection{Statistical analyses}

We first used t-tests for paired samples to compare the values of indicators and criteria between the two habitats. A standardized principal component analysis (PCA), with criteria as variables, was used to visually assess which criteria best explained the differences between samples. Dependence of PCA coordinates on elevation and classes of aspect were respectively tested with linear regression and 
Table II. Classes used in this study to quantify the different indicators of naturalness and conservation. Criterion calculations are in bold characters. Scarcity of plant group (DRS/hab), Sensitivity/Vulnerability of the site (FV), Remarkable structural stand features (Rem. elts.) are considered as criteria because they are only composed of one indicator.

Table II. Classes used in this study to quantify the different indicators of naturalness and conservation. Criterion calculations are in bold characters. Scarcity of plant group (DRS/hab), Sensitivity/Vulnerability of the site (FV), Remarkable structural stand features (Rem. elts.) are considered as criteria because they are only composed of one indicator.

\begin{tabular}{|c|c|c|c|c|c|c|}
\hline \multirow{2}{*}{$\begin{array}{l}\text { (a) } \\
\text { Indicator value }\end{array}$} & \multicolumn{6}{|c|}{ Natural Value (NV) } \\
\hline & 0 & 1 & 2 & 3 & 4 & 5 \\
\hline$\%$ cover of native tree $(\mathrm{A})$ & $<1$ & 1 to 29 & 30 to 59 & 60 to 79 & 80 to 99 & $100 \%$ \\
\hline Phytocœnosis integrity (IP) & $<0.3$ & 0.3 to 0.6 & 0.6 to 0.9 & 0.9 to 1.2 & 1.2 to 1.5 & $>1,5$ \\
\hline Naturalness of Composition & \multicolumn{6}{|c|}{$(\mathrm{A}+\mathrm{IP}) / 2$} \\
\hline Eco-unit size (ha) $(\mathrm{T})$ & $>10$ & 5 to 10 & 1 to 5 & 0.5 to 1 & 0.2 to 0.5 & $<0.2$ \\
\hline \multicolumn{7}{|l|}{ Vertical heterogeneity (HV) : } \\
\hline \multirow{3}{*}{$\begin{array}{l}\text { Colonisation phase } \\
\text { Competition phase } \\
\text { Maturity and declining phase }\end{array}$} & $<0.05$ & 0.05 to 0.1 & 0.1 to 0.2 & 0.2 to 0.3 & 0.3 to 0.4 & $>0.4$ \\
\hline & $<0.05$ & 0.05 to 0.1 & 0.1 to 0.15 & 0.15 to 0.2 & 0.2 to 0.25 & $>0.25$ \\
\hline & $<0.1$ & 0.1 to 0.2 & 0.2 to 0.3 & 0.3 to 0.4 & 0.4 to 0.6 & $>0.6$ \\
\hline \multicolumn{7}{|l|}{ Amount of dead wood per hectare $(\mathrm{N})$} \\
\hline Colonisation and competition phase $\left(\mathrm{m}^{3} / \mathrm{ha}\right)$ & $<2$ & 2 to 5 & 5 to 10 & 10 to 20 & 20 to 30 & $>30$ \\
\hline Maturity and declining phase $\left(\mathrm{m}^{3} / \mathrm{ha}\right)$ & $<5$ & 5 to 10 & 10 to 20 & 20 to 40 & 40 to 60 & $>60$ \\
\hline Naturalness of Structure & \multicolumn{6}{|c|}{$(\mathrm{T}+\mathrm{HV}+\mathrm{N}) / 3$} \\
\hline Silvicultural treatment $(\mathrm{R})$ & $\begin{array}{l}\text { Exploited } \\
\text { coppice }\end{array}$ & $\begin{array}{l}\text { Coppice } \\
\text { with stan- } \\
\text { dards }\end{array}$ & $\begin{array}{l}\text { Plantation or high } \\
\text { forest growing on } \\
\text { stumps }\end{array}$ & $\begin{array}{l}\text { High forest } \\
\text { from natural } \\
\text { regeneration }\end{array}$ & $\begin{array}{l}\text { Unharves- } \\
\text { ted coppice }\end{array}$ & $\begin{array}{l}\text { Unharves- } \\
\text { ted high } \\
\text { forest }\end{array}$ \\
\hline Human intervention (total) (I) & \multicolumn{6}{|c|}{ Strong logging, harvesting impact, fertilisation, drainage $=-1$} \\
\hline Total export of ligneous biomass (EP) & 5 stumps & 4 & 3 & 2 & 1 & 0 \\
\hline Intensity of tourist activity (PT) & $\begin{array}{l}\text { Very } \\
\text { strong }\end{array}$ & Strong & Medium & Weak & Very weak & None \\
\hline Naturalness of Function & \multicolumn{6}{|c|}{$(\mathrm{R}+\mathrm{I}+\mathrm{EP}+\mathrm{PT}) / 4$} \\
\hline Natural Value (NV) & \multicolumn{6}{|c|}{$($ Composition + Structure + Function $) / 3$} \\
\hline
\end{tabular}

\begin{tabular}{lcccccc}
\hline (b) & \multicolumn{5}{c}{ Conservation Value (CV) } \\
\hline Indicator value & 0 & 1 & 2 & 3 & 4 & 5 \\
Number of vascular plant species per plot & $<10$ & 10 to 20 & 21 to 30 & 31 to 40 & 41 to 50 & $>50$
\end{tabular}

(S)

Scarcity of vascular plant species* $(\mathrm{Re})$

Species diversity / scarcity

Scarcity of plant group* (DRS/hab)

Sensitivity/Vulnerability of the site (FV)

Remarkable structural stand features

(Rem. elts.)
See text for calculation and Appendix 1 for value for each species

$$
\mathrm{S} * \mathrm{Re} / 5
$$

$\begin{array}{cccccc}\text { Ordinary } & \text { Widespread } & \begin{array}{c}\text { Not very } \\ \text { widespread }\end{array} & \text { Medium rare } & \text { Rare } & \text { Very rare } \\ \text { None } & \text { Weak } & \text { Quite weak } & \text { Medium } & \text { Strong } & \text { Very strong }\end{array}$

Exceptional amount of dead trees/deadwood per plot, canopy stratification, trees with holes, remarkable trees $=+1$

\footnotetext{
* Based on European, Regional and local inventories and red lists.
} 
one way ANOVA. We then focused our analyses on natural and conservation values (NV and $\mathrm{CV}$ ) as global criteria for the ecological value of both habitats. To test for possible dependence between NV and CV in the two habitats, we used Spearman's rank correlation test. We used t-tests for independent samples for NV, and switched to a non-parametric Mann-Whitney U-test for CV, to compare the values between Phyllitido- and Arunco-Aceretum associations (19 samples). As our sampling design consisted of dependent paired plots, we used linear mixed effect models with $\mathrm{NV}$ and $\mathrm{CV}$ as variables to be explained, sites as a random factor and habitat (sycamore or mixed forest), elevation (continuous variable), aspect (three levels: N-NE; E-SE-W-NW, S-SW) and their interactions as fixed factors. These analyses were processed on S-PLUS ${ }^{\circledR}$ software 6.2 (Insightful Corp., 2003). All the tests were considered significant for $P<0.05$.

\section{RESULTS}

The ecological value was higher for sycamore habitats than for the surrounding mixed forests. The natural/conservation values never reached the maximum value of five, but 7 plots scored or exceeded the value of three. Some indicators were constant whatever the plot: (i) the cover of native trees was systematically maximum (100\%); (ii) we were not able to evaluate the indicator "scarcity of the plant group" based on field experience as recommended by Du Bus de Warnaffe and Devillez (2002). Thus, solely on the basis of European references (European Commission, 2003), the value 4 ("rare plant group") was attributed to sycamore habitats and the medium value 2 ("Not very widespread plant group") was attributed to the habitats of mixed forests.

We found significant differences between sycamore and mixed forest stands for naturalness of composition, structure and function, as well as for some of the indicators used to calculate the criterion values. Hence, the phytocœnosis integrity, the eco-unit size, the silvicultural treatment and the ligneous biomass export were significantly different between the habitats (Tab. III). Among the components of CV, the only marginally significant difference concerned sensitivity/vulnerability of the site.

The PCA on the criterion variables clearly separated sycamore habitats from mixed forest on the basis of their ecological value (Fig. 2). The first axis of the PCA represented $34 \%$ of the variance and was correlated with naturalness of structure $(r=0.52)$, scarcity of the plant group $(r=0.43)$ and sensitivity/vulnerability of the site $(r=-0.43)$. The second axis represented $26 \%$ of the variance and referred to a gradient of naturalness of composition $(r=0.66)$ and scarcity and diversity of vascular plant species $(r=0.62)$. The third axis represented $14 \%$ of the variance and was correlated with remarkable features $(r=-0.71)$ and naturalness of function $(r=0.48)$. The first gradient differentiated most of the sycamore habitats from the mixed forests but some mixed forest sites were differentiated only on the second axis. The third axis did not differentiate the two habitats but was nonetheless interesting because it emphasized features common to both habitats. The only significant correlation between PCA factorial coordinates and elevation concerned the second axis but did not show high levels of correlation $\left(R^{2}=0.08, P<0.05\right)$.

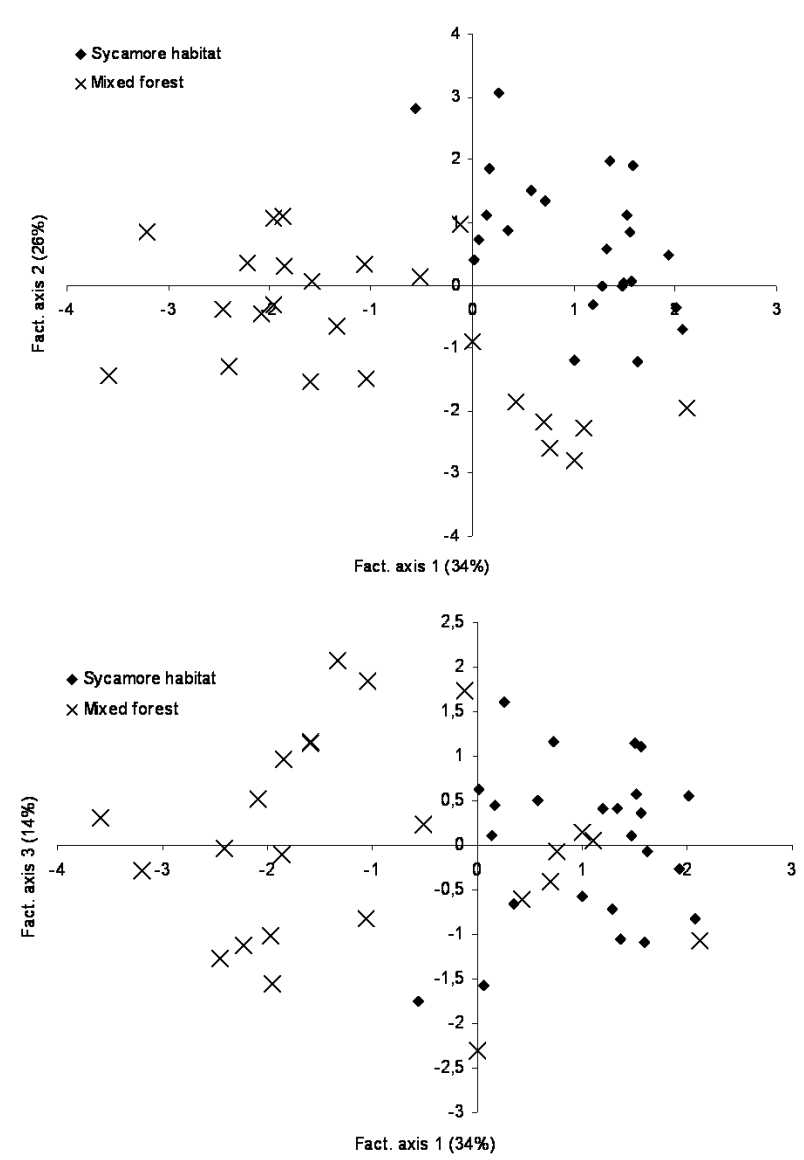

Figure 2. Projections of the observations (plots) on the three first axes of a standardized Principal Components Analysis. Seven criteria were used as variables: naturalness of composition, structure and function, species diversity and scarcity, scarcity of the plant group, sensitivity and vulnerability of the site and remarkable structural stand features. Figures in brackets represent the percentage of variance for each axis.

We only detected a significant effect of aspect on the third axis $(F=4.194, P<0.05)$.

To sum up, NV and CV were significantly different between the two habitats and sycamore habitats tended to show a higher ecological value than the surrounding mixed forests (Fig. 3). Spearman's rank correlation tests showed different levels of correlation between $\mathrm{CV}$ and $\mathrm{NV}$ for the two habitats: $\mathrm{NV}_{\text {sycamore }}$ vs. $\mathrm{CV}_{\text {sycamore }}(\rho=-0.18, P=0.6)$ and $\mathrm{NV}_{\text {mixed forest }} \mathrm{vs}$. $\mathrm{CV}_{\text {mixed forest }}(\rho=0.06 ; P=0.79)$ show nonsignificant correlations; $\mathrm{CV}_{\text {sycamore }}$ vs. $\mathrm{CV}_{\text {mixed forest }}(\rho=0.36$, $P=0.08$ ) showed marginally significant results but a relatively low level of correlation; the only significant correlation linked $\mathrm{NV}_{\text {sycamore }}$ and $\mathrm{NV}_{\text {mixed forest }}(\rho=0.47, P=0.02)$ with a moderate level of correlation. The association type (Arunco-Aceretum vs. Phyllitido-Aceretum) influenced neither $\mathrm{NV}(t=-0.246, d f=17, P=0.81)$ nor $\mathrm{CV}(Z=-1.183$, $d f=17, P=0.24)$ of the sycamore habitats. The respective influence of habitat type, elevation and aspect was tested with 
Table III. Indicator and criteria (in bold) values ( \pm S.D.) for the 24 comparisons between sycamore habitats and mixed fir-beech-spruce forests. $p$-values for paired $t$-tests $(n=24)$ are given for each comparison.

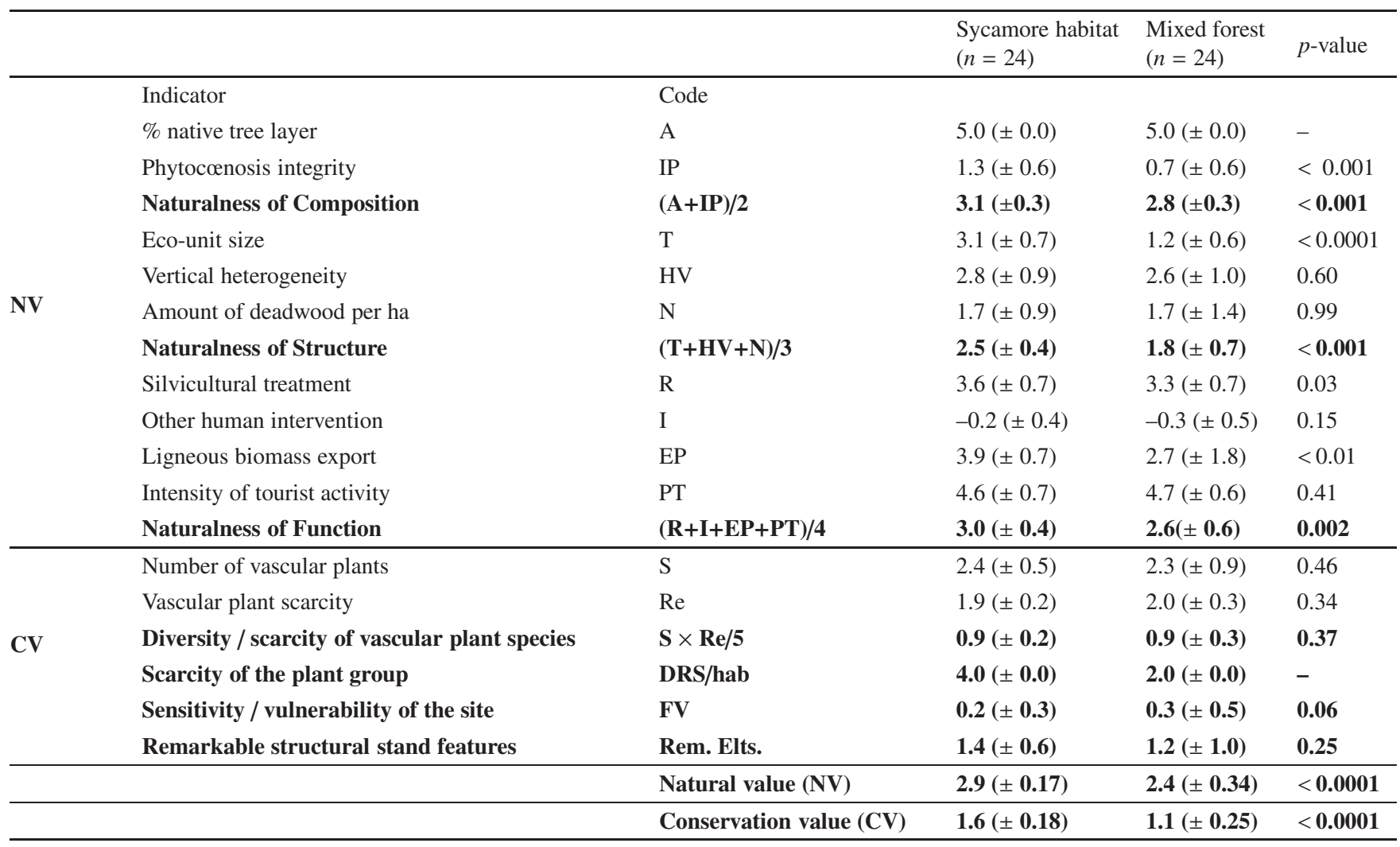

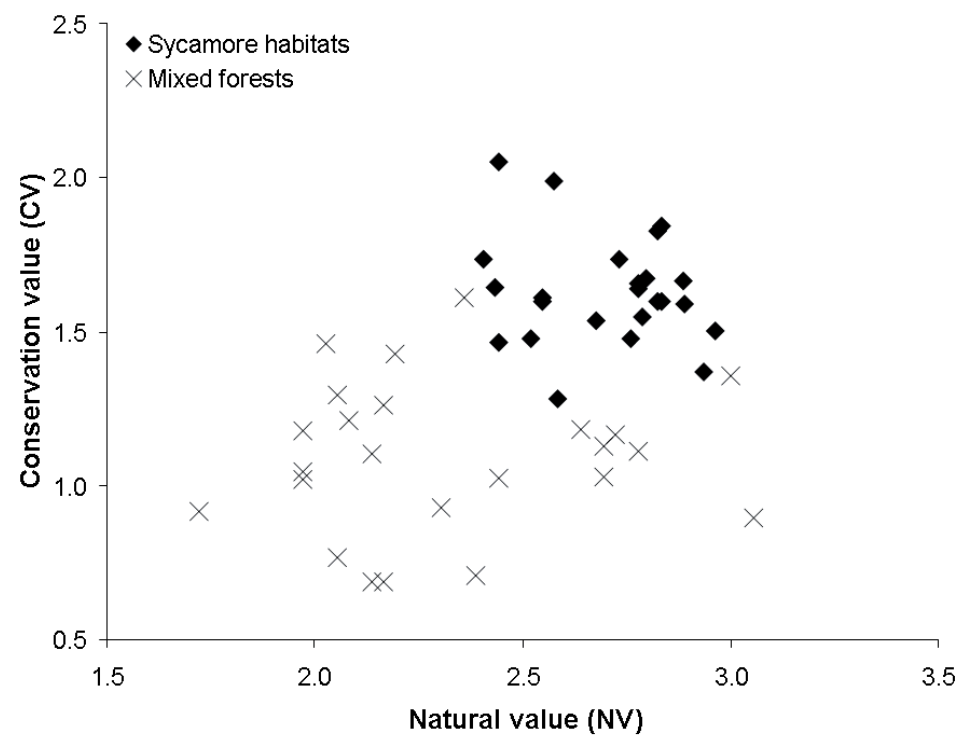

Figure 3. Comparison of Natural Value (NV) and Conservation Value (CV) for sycamore habitats and mixed forests. 
Table IV. ANOVA testing the effects of habitat, elevation and aspect on Natural (NV) and Conservation (CV) values. Paired samples were integrated in a linear mixed effect model with sites as a random factor. Significant results at the $5 \%$ level are in bold characters. $d f=$ degrees of freedom.

\begin{tabular}{lccc}
\hline Factor tested $(n=48)$ & $d f$ & $F$-value & $p$-value \\
\hline NV & $\mathbf{2}$ & $\mathbf{1 4 1 5 . 6 1 1}$ & $<\mathbf{0 . 0 0 0 1}$ \\
Habitat & 1 & 0.923 & 0.35 \\
Elevation & 2 & 0.196 & 0.82 \\
Aspect & 1 & 0.001 & 0.97 \\
Habitat $\times$ Elevation & 2 & 2.252 & 0.14 \\
Habitat $\times$ Aspect & 2 & 0.242 & 0.79 \\
Elevation $\times$ Aspect & 2 & 0.660 & 0.53 \\
Habitat $\times$ Elevation $\times$ Aspect & & & \\
CV & $\mathbf{2}$ & $\mathbf{7 7 5 . 5 7 6}$ & $<\mathbf{0 . 0 0 0 1}$ \\
Habitat & 1 & 2.361 & 0.15 \\
Elevation & 2 & 1.154 & 0.35 \\
Aspect & 1 & 0.294 & 0.60 \\
Habitat $\times$ Elevation & 2 & 1.734 & 0.22 \\
Habitat $\times$ Aspect & 2 & 0.102 & 0.90 \\
Elevation $\times$ Aspect & 2 & 1.128 & 0.35 \\
Habitat $\times$ Elevation $\times$ Aspect & & &
\end{tabular}

ANOVA (Tab. IV). Habitat type was the only factor that significantly influenced NV and CV. None of the other factors or interactions tested was significant.

\section{DISCUSSION}

\subsection{The ecological value of sycamore habitats}

The multi-criterion method allowed us to quantify the ecological value empirically given by naturalists to sycamore habitats in comparison with the surrounding beech-fir-spruce forest. Sycamore habitats showed significantly higher CV and $\mathrm{NV}$ than the surrounding mixed forests. The differences found between these two habitats can be attributed to indicators of naturalness more than to those of conservation. Forest naturalness has often been used as a criterion in conservation value assessment (e.g. Kuuluvainen, 2002; Uotila et al., 2002). In our case, the main criteria that differentiated sycamore and mixed forests habitats were naturalness of structure and composition. Indeed, the protected status of sycamore habitats as well as their poor economic value and their role in soil protection probably explain why these habitats are less affected by management than the surrounding mixed forests. As a consequence, these small habitats show more features of natural forests (e.g. small eco-unit sizes, large trees) than the mixed forest. This result proves to a certain extent that the preservation policy is having positive effects on these habitats.

However, the observed difference in conservation values between the two habitats was mainly a consequence of the higher value attributed to the scarcity of the plant group based on European references, and to a lesser extent to the sensitivity/vulnerability of the site for sycamore habitats. This means that the value of $\mathrm{CV}$ was not based on field experience but rather on a larger scale assessment. Actually, we seldom recorded rare vascular plants in sycamore habitats and the species we found are known to grow in a variety of habitats e.g. Aconitum paniculatum or Campanula latifolia (Rameau et al., 2000; Rameau et al., 1993). Furthermore, in our samples we never observed any of the very few rare and threatened species reported in the literature (Clot, 1990; Rameau et al., 2000), which are more or less restricted to sycamore habitats such as Asperula taurina or Achillea macrophylla. Threatened and rare species are considered to be good indicators of forest ecological value (e.g. Gustafsson and Hallingback, 1988), but in our case the conservation value of sycamore habitats relied on other factors. Nor did remarkable structural features, such as canopy structure or the amount of deadwood, differentiate the sycamore habitats from the paired mixed forests (Fig. 2). These results account for the fact that the criteria approach is complementary to the approach by indicators, since indicators alone are not sufficient to differentiate the two habitats in terms of ecological value.

NV and CV varied relatively independently within each habitat; this means that a site may have features of natural forest but weak potential to host species of conservation interest. This also means that some "virgin" sites may be of lower conservation value than certain managed sites. Up to a point, disturbances are known to have potentially positive impacts on biodiversity by limiting the occurrence of dominant species (Standovar et al., 2006). The dilemma is to choose which sites to protect first when weighing "virgin" sites of low conservation value and less natural sites of high conservation value. It may hence be necessary for the manager to give more weight to one of the two criteria, based on his own local knowledge. Moreover, CV and NV were (marginally) correlated between habitats. This is probably a site effect since the paired plots were situated in similar ecological conditions and had more or less the same history. For example, sites at higher elevations or those difficult to access have classically been less intensively managed than more accessible sites (Sebastia et al., 2005; Standovar et al., 2006). However, this was neither clearly confirmed by the tests on PCA coordinates, which showed little influence of elevation and aspect on the distribution of the plots in the first factorial plans, nor by ANOVA, which showed no influence of elevation on NV or on CV (Tab. IV). Nevertheless, it is interesting to note that although neighbouring habitats have close CV and NV values, they have distinct flora: this shows that the difference between habitats does not simply stem from source-sink functioning (i.e. the fact that species from the sycamore habitat might for example be found nearby in the mixed forest), but that each habitat provides specific conditions for vascular plants.

At the association level, there was no difference between Phyllitido- and Arunco-Aceretum either in terms of NV or $\mathrm{CV}$. However, we could not test these differences for the other Tilio-Acerion associations, which could have been interesting since subalpine associations are known to be species richer than mountainous associations (Rameau et al., 2000). 
The linear mixed effect model analysis showed that none of the tested abiotic factors other than habitat type significantly influenced the variations in NV and CV. Hence, these values seem to vary quite independently from elevation and aspect despite the differences in floristic composition of sycamore habitats and mixed forests in our sample.

\subsection{Limits and possible improvements}

Although the high ecological value of sycamore habitats was confirmed by our results, the method could be improved on some points. In the case of sycamore habitats - and more generally of small fragmented habitats - the limits of the forest management units did not match the natural limits of the habitats. Thus, our assessment did not benefit from existing data sometimes available at the management scale (such as inventories of saproxylic insects or cavity-nesting birds) despite their importance in terms of conservation. Our assessment should be seen as a compromise between efficiency and relevance of the indicators sampled. The field protocols used to evaluate the ecological value must be cost- and time-effective in order to be accepted by managers. For this reason, we deliberately recorded some indicators, like deadwood, eco-unit size or export of ligneous biomass, directly in classes, although this method was partly subjective. The implementation and repeatability of the assessment would benefit from the use of standardized methods which, in some cases, remain costand time-effective (see e.g. Marage and Lemperiere, 2005 for deadwood).

Integration of the sycamore habitats into an ecological network was not evaluated for technical and practical reasons. Sycamore habitat dynamics are probably conditioned by substrate quality and activity (Paillet and Brun, 2004; Rameau et al., 2000), and landscape features like connectivity or isolation might not influence population dynamics as much as it could for other habitats or species. However, species dispersal ability between patches of sycamore habitats or dependence upon these habitats are poorly known (e.g. for species of saproxylic beetles, B. Dodelin, pers. com.) and could not be assessed in our study. As ecological networks play a key role in defining the ecological value in landscapes (e.g. Ferré et al., 2005; Machado, 2004), our evaluation would have benefited from precise habitat maps.

\subsection{The role of sycamore habitats in the mountain landscape}

The method we used allowed us to quantify the ecological value of sycamore habitats by comparison to the surrounding homogenous mixed forest. Even if the patches of sycamore habitats are no richer than the mixed forest in terms of vascular plants, they host different plant communities. At the landscape scale, sycamore habitats may also contribute to the diversity of soil-dwelling species and humus forms (Ayres et al., 2006; Breton et al., 2005; Neirynck et al., 2000), criteria that were not included in our assessment. For example, the recently discovered earthworm species Octodrilus juvyi has only been described in the sycamore habitats of the Chartreuse (Zicsi and Cuendet, 2005). Therefore, we think that these habitats probably provide refuges or niches for species; preserving them is important for biodiversity at the landscape scale.

Acknowledgements: We are grateful to Nathalie Cassagne, Emmanuelle Dauffy-Richard and Frédéric Gosselin for their valuable comments and statistical advice on the first drafts of this paper. We also thank Victoria Moore for polishing the language. Damien Marage and an anonymous reviewer provided interesting comments and discussion on this paper. This research was funded by the French Ministry in charge of the Environment (grant No. 1688). We are also grateful to the "Parc Naturel Régional de Chartreuse" for supporting this study.

\section{REFERENCES}

Anderson J.E., 1991. A conceptual-framework for evaluating and quantifying naturalness. Conserv. Biol. 5: 347-352.

Angermeier P.L., 2000. The natural imperative for biological conservation. Conserv. Biol. 14: 373-381.

Archaux F., Gosselin F., Berges L., and Chevalier R., 2006. Effects of sampling time, species richness and observer on the exhaustiveness of plant censuses. J. Veg. Sci. 17: 299-306.

Ayres E., Dromph K.M., and Bardgett R.D., 2006. Do plant species encourage soil biota that specialise in the rapid decomposition of their litter? Soil Biol. Biochem. 38: 183-186.

Bartha D., 2004. Chances for a stand-level evaluation of the naturalness of forests. All. Forst. Jagdz. 175: 8-13.

Bartha D., Odor P., Horvath T., Timar G., Kenderes K., Standovar T., Bölöni J., Szmorad F., Bodonczi L., and Aszalos R., 2006. Relationship of tree stand heterogeneity and forest naturalness. Acta. Silv. Lign. Hung. 2: 7-22.

Bartoli C., 1962. Première note sur les associations forestières du massif de la Grande Chartreuse. Annales de l'École Nationale des Eaux et Forêts et de la station recherches et expériences XIX: 328-382.

Beazley K., Smandych L., Snaith T., Mackinnon F., Peter Austen-Smith J.R., and Duinker P., 2005. Biodiversity considerations in conservation system planning: Map-based approach for Nova Scotia, Canada. Ecol. Appl. 15: 2192-2208.

Braun-Blanquet J., 1932. Plant Sociology, McGraw-Hill Book Company, New York, USA, 439 p.

Breton V., Paillet Y., Juvy B., Cassagne N., Cecillon L., and Brun J.J., 2005. Dynamique des érablaies de versant et diversité pédofaunistique des humus. Eléments pour la gestion conservatoire de ces habitats au sein du PNR de Chartreuse. Cemagref Grenoble, PNR de Chartreuse.

Bridge S.R.J., Cooligan D., Dye D., Moores L., Niemann T., and Thompson R., 2005. Reviewing Canada's national framework of criteria and indicators for sustainable forest management. For. Chron. 81: 73-80.

Brossier J., 1954. Massif de la Grande Chartreuse : notice descriptive. Eaux et Forêts.

Chevallier P. and Couailhac M.-J. (Eds.), 1983. L'administration des eaux et forêts dans le département de l'Isère au XIXe siècle : sauvegarde et reconstitution du patrimoine. Université des sciences sociales de Grenoble 99 p.

Clot F., 1990. Les érablaies européennes : essai de synthèse. Phytocoenologia 18: 409-564. 
Colak A.H., Rotherham I.D., and Calikoglu M., 2003. Combining "naturalness concepts" with close-to-nature silviculture. Forstwiss. Centbl. 122: 421-431.

Du Bus de Warnaffe G. and Devillez F., 2002. Quantifier la valeur écologique des milieux pour intégrer la conservation de la nature dans l'aménagement des forêts : une démarche multicritères. Ann. For. Sci. 59: 369-387.

Ehrlich P.R., 1996. Conservation in temperate forests: what do we need to know and do? For. Ecol. Manage. 85: 9-19.

European Commission, 2003. Interpretation manual of European Union habitats. http://europa.eu.int/comm/environment/nature/legis.htm.

Ferré A., Carreras J., Carrillo E., and Ninot J.M., 2005. Assessing the natural interest of the landscapes of Andorra, a mountain country under contrasted land use changes. Acta Bot. Gallica 152: 443-455.

Frego K., 2007. Bryophytes as potential indicators of forest integrity. For. Ecol. Manage. 242: 65-75.

Gotmark F., 1992. Naturalness as an Evaluation Criterion in Nature Conservation. Conserv. Biol. 6: 455-458.

Gustafsson L. and Hallingback T., 1988. Bryophyte flora and vegetation of managed and virgin coniferous forests in South-West Sweden. Biol. Conserv. 44: 283-300.

Korpel S., 1995. Die Urwälder des Westkarpaten, Gustav Fischer, Stuttgart, Jena, New York, 312 p.

Kuuluvainen T., 2002. Natural variability of forests as a reference for restoring and managing biological diversity in boreal Fennoscandia. Silva Fenn. 36: 97-125.

Lavauden L., 1905. Recherches sur la flore du Massif de la Grande Chartreuse : essai de phytostatique appliquée. Annales de l'Institut National d'Agronomie 4: 1-69.

Lindenmayer D.B., Margules C.R., and Botkin D.B., 2000. Indicators of biodiversity for ecologically sustainable forest management. Conserv. Biol. 14: 941-950.

Machado A., 2004. An index of naturalness. J. Nat. Conserv. 12: 95-110.

Marage D. and Lemperiere G., 2005. The management of snags: A comparison in managed and unmanaged ancient forests of the Southern French Alps. Ann. For. Sci. 62: 135-142.

Neirynck J., Mirtcheva S., Sioen G., and Lust N., 2000. Impact of Tilia platyphyllos Scop., Fraxinus excelsior L., Acer pseudoplatanus L.,
Quercus robur L. and Fagus sylvatica L. on earthworm biomass and physico-chemical properties of a loamy topsoil. For. Ecol. Manage. 133: 275-286.

Neumann M. and Starlinger F., 2001. The significance of different indices for stand structure and diversity in forests. For. Ecol. Manage. 145: 91-106.

Oldeman R.A.A., 1990. Forests: elements of silvology, Springer-Verlag, Berlin, $624 \mathrm{p}$.

Pache G., 1998. Catalogue détaillé des stations forestières du Massif de la Chartreuse et des chaînons calcaires du pays "entre Jura-Savoie". Laboratoire Écosystèmes Alpins, Université Joseph Fournier, Grenoble.

Paillet Y. and Brun J.-J., 2004. Approche synchronique de la dynamique des érablaies de versant dans le Massif de la Chartreuse. Rev. For. Fr. LVI: 337-350.

Peterken G.F., 1996. Natural Woodland - ecology and conservation in nothern temperate regions, Cambridge University Press, Cambridge, $536 \mathrm{p}$.

Rameau J.-C., Gauberville C., and Drapier N. (Eds.), 2000. Gestion forestière et diversité biologique : identification et gestion intégrée des habitats et espèces d'intérêt communautaire. France, domaine continental. Vol. 2, ENGREF, ONF, IDF, 178 p.

Rameau J.-C., Mansion D., and Dumé G., 1993. Flore Forestière Française, Tome 2 : Montagnes, Institut pour le Développement Forestier, $2421 \mathrm{p}$.

Sebastia M.T., Casals P., Vojnikovic S., Bogunic F., and Beus V., 2005. Plant diversity and soil properties in pristine and managed stands from Bosnian mixed forests. Forestry 78: 297-303.

Siipi H., 2004. Naturalness in biological conservation. J. Agric. Environ. Ethics 17: 457-477.

Standovar T., Odor P., Aszalos R., and Galhidy L., 2006. Sensitivity of ground layer vegetation diversity descriptors in indicating forest naturalness. Community Ecol. 7: 199-209.

Uotila A., Kouki J., Kontkanen H., and Pulkkinen P., 2002. Assessing the naturalness of boreal forests in eastern Fennoscandia. For. Ecol. Manage. 161: 257-277.

Zicsi A. and Cuendet G., 2005. Über eine neue Octodrilus-Art aus Frankreich (Oligochaeta: Lumbricidae). Rev. Suisse Zool. 112: 329_ 331. 
Appendix 1. Remarkable and rare species in the Chartreuse range and values used to calculate the individual scarcity indicator. References used for the classification are European (Habitat Directive), National and Regional (red lists and special protection status) and local (remarkable species in the Chartreuse). Ordinary species received the value 1. Nomenclature follows Rameau (Rameau et al., 1993).

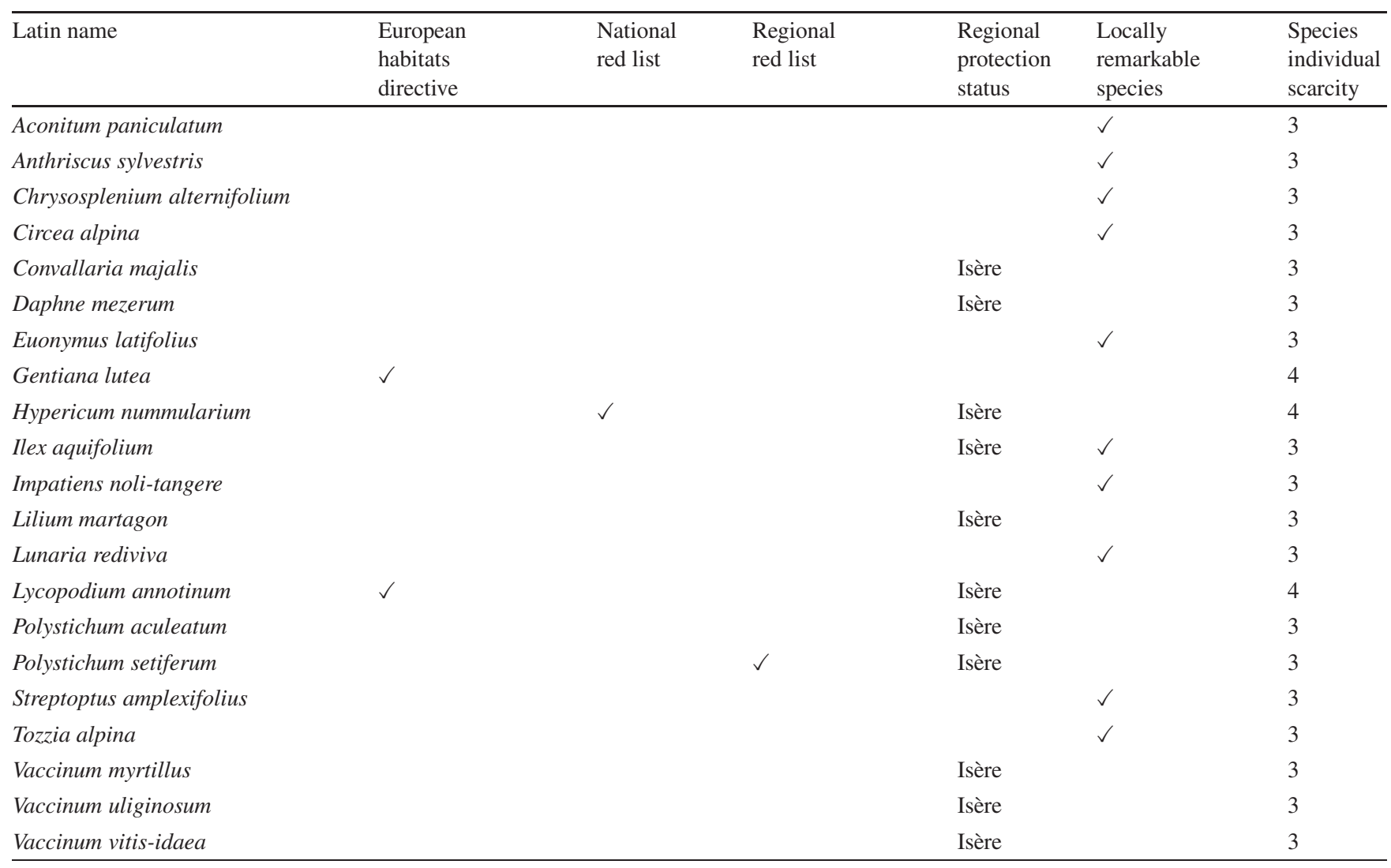

